\title{
Explaining shifts in systematic risk after merger: Some empirical evidence
}

\author{
G.D.I. Barr and R.C. van den Honert \\ Department of Mathematical Statistics, University of Cape Town, Private Bag, Rondebosch, 7700 Republic of South Africa
}

Accepted 7 April 1988

\begin{abstract}
In this paper we discuss the change in the beta of an acquiring firm after merger, and examine the unexplained difference between the beta predicted by capital market theory and the beta actually calculated. The analysis is done within two different frameworks, equity beta on the one hand and asset beta (which removes leverage effects from equity beta) on the other. It is found that by using an asset beta approach proportionately more of the beta shifts can be explained by characteristics of the target and acquiring firms than when using the equity beta approach. It is hypothesized that the asset beta approach, which removes the confounding nonlinear effect of debt, constitutes a superior framework to examine shifts in beta.
\end{abstract}

In hierdie artikel bespreek ons die verandering in die sistematiese risiko (beta) van 'n óornemende maatskappy na samesmelting en ons ondersoek die onverklaarde verskil tussen die beta wat deur kapitaalmarkteorie voorspel word en die beta wat werklik bereken word. Die analise word aan die hand van twee verskillende raamwerke gedoen: enersyds volgens aandeelbetas en andersyds volgens batebetas (wat die effek van skuld van die aandeelbeta verwyder). Daar is bevind dat as die batebenadering gebruik word, word eweredig meer van die betaverandering deur die eienskappe van die oorgenome en oornemende maatskappye verduidelik as wanneer die aandeelbetabenadering gebruik word. Daar word veronderstel dat die batebenadering, wat die verwarrende nie-lineêre effek van skuld verwyder, 'n meer voortreflike raamwerk is om die veranderings in beta te ondersoek.

\section{Introduction}

The high level of merger activity on international markets in recent years has given rise to substantial work on the subject in the financial literature. A large body of that research has dealt with the abnormal returns realized by shareholders of the acquiring and target firms ${ }^{1}$. Less attention has been given to the analysis of the risk profile of the merged company. Under certain assumptions capital market theory allows us to form estimates of the systematic risk (beta) of a merged firm in terms of the betas of the component firms. In this paper we examine the shifts that may take place in the beta of a merged company from that which capital market theory implies. In addition, in order to abstract from any complications of debt restructuring the analysis is carried out using ungeared or intrinsic betas.

\section{Previous research}

Joehnk \& Nielsen (1974) and Thompson (1983) have studied the extent to which the pre-merger values of systematic risk for the acquiring and target firms affect the post-merger change in systematic risk of the merged firm. They used a multiple regression model to explain the change in betas of merged companies by a number of variables describing pre-merger characteristics of the acquirer and target. Thompson, for example, used as dependent variable an estimate of the difference in beta for the acquiring firm before and after the merger, and as independent variables the following:

- the absolute difference in pre-merger betas for acquiring and target firms

- the difference in pre-merger variance of returns relative to the acquiring firm's variance

- the relative size of the market value of equity of the acquired firm to the acquiring firm prior to the merger

- the market capitilization of the acquiring firm
- the degree of conglomerateness of the merger ${ }^{2}$

- the ratio of the long-term debt to total assets averaged over a period before and after the merger.

Acquisition of another firm will almost certainly lead to a change, however small, in the financial and intrinsic structure and thus beta of the merged firm ${ }^{3}$, and clearly the beta of the merged firm will to some extent depend on the above variables. By examining this difference rather than simply attempting to model the absolute values of pre- and post-merger differences in beta, the focus is shifted to explaining shifts in systematic risk which capital market theory cannot explain. Furthermore, mergers almost always involve some debt restructuring which may confound any analysis based on equity betas. In order to remove this effect and offer a different angle on the analysis, betas were computed with the debt effect removed. Such betas are known as ungeared or intrinsic betas ${ }^{4}$.

\section{The expected post-merger equity beta}

Consider an acquiring firm and a target firm involved in a merger. Let $\beta A_{1}$ and $\beta A_{2}$ be the equity beta coefficients of the acquiring firm before and after the merger, respectively, and let $\beta T_{1}$ be the equity beta of the target firm before the merger. Capital market theory predicts that the equity beta of any amalgamation of securities is the market capitalization weighted average of the component securities' betas. In the case of a merger between two firms this allows us to form an unbiased prediction of the beta of the merged firm on the basis of the equity betas of the acquiring and target firms. ${ }^{5}$ Thus

$E\left(\beta A_{2}\right)=\left(\frac{M C A}{M C A+M C T}\right) \hat{\beta} A_{1}+\left(\frac{M C T}{M C A+M C T}\right) \hat{\beta} T_{1}$ 
where $E\left(\beta A_{2}\right)$ is the capital market theory prediction of the post-merger beta of the resultant acquiring firm; $\hat{\beta} A_{1}$ is the ordinary least squares estimate of the equity beta of the acquiring firm prior to the merger announcement (market model); $\hat{\beta} T_{1}$ is the ordinary least squares estimate of the equity beta of the target firm prior to the merger announcement (market model); and $M C A$ and $M C T$ are the market capitalizations of the acquiring and target firms prior to the merger, respectively ${ }^{6}$.

Any differences between $E\left(\beta A_{2}\right)$ and $\hat{\beta} A_{2}$ (the ordinary least squares estimate of the post-merger equity beta of the resultant acquiring firm) represent unexplained shifts in systematic risk which are not accounted for under the assumptions of capital market theory and form the dependent variable of focus in this study. Previous approaches (e.g. Thompson, 1983) have simply considered $\hat{\beta} A_{2}-\hat{\beta} A_{1}$, which downweights the possible effect of $\beta T_{1}$. Note however that these two alternative ways of computing beta difference will be equal when $\hat{\beta} A_{1}=\hat{\beta} T_{1}$.

\section{Removing the debt effect from beta}

Hamada (1972) and Rubinstein (1973) developed a relationship between the market beta before and after debt financing. This equation can be written as follows:

$\beta=\left(1+(1-t) D / E_{q}\right) \times \beta^{*}$

where $\beta^{*}$ is the beta with no debt financing, $D$ is the market value of $\operatorname{debt}^{7}, E_{q}$ is the market value of the firm's stock after debt financing (i.e. the firm's equity) and $t$ is the tax rate of the firm.

Equation (2) shows how financial structure levers up intrinsic beta in a non-linear way and thus an attempt to model the equity beta as a linear function of debt, or equity, or the debt to asset ratio (see Thompson, 1983) represents an approximation. Alternatively, by removing the effect of debt from the equity beta and modelling the intrinsic beta one can focus on the aspects of systematic risk which are unrelated to financial structure.

Following the methodology of the previous section we may formulate equation (1) to describe the expected asset beta of the merged firm as follows:

$$
E\left(\beta^{*} A_{2}\right)=\frac{E_{4}}{(1-t) D+E_{q}}\left[\left(\frac{M C A}{M C A+M C T}\right) \hat{\beta} A_{1}+\left(\frac{M C T}{M C A+M C T}\right) \hat{\beta} T_{1}\right]
$$

where $E\left(\beta^{*} A_{2}\right)$ is the expected value of the asset beta for the merged firm;

$$
\frac{E_{q}}{(1-t) D+E_{q}} \text { is the equity to debt plus equity ratio of the }
$$$$
\text { resultant acquiring firm adjusted for tax. }
$$

The calculated observed value of the asset beta of the merged firm is:

$$
\hat{\beta} A_{2}=\left(\frac{E_{q}}{(1-t) D+E_{q}}\right) \hat{\beta} A_{2},
$$

and thus the difference between the above quantities $\left(E\left(\beta^{*} A_{2}\right)-\hat{\beta}^{*} A_{2}\right)$ represents the deviation of the asset beta from its predicted value under the assumptions of capital market theory.

\section{Explanation of beta (equity and asset) shifts}

In order to explain the difference between predicted (under capital market theory) and calculated beta for the equity beta and asset beta approaches, a regression analysis was performed on the data discussed above with these differences in betas as the dependent variable. The focus of this study thus becomes the explanation of postmerger shifts in the beta of a merged firm from the beta of a premerger portfolio consisting of shares of the target and acquiring firms held in their market capitilization proportions. In contrast Thompson (1983) and Joehnk \& Nielsen (1974) used regression analysis to explain the actual change in the beta of the acquiring frim before and after the merger. This analysis thus explicitly includes the size and risk profile of the target firm whereas the studies of Thompson and Joehnk \& Nielsen do not.

In order to explain these risk shifts away from the predicted beta, several market-related explanatory variables are considered, similar to those used by Joehnk \& Nielsen and Thompson. As in their analyses, accounting variables were ignored due to the difficulties involved in getting meaningful comparative measures ${ }^{8}$. The regression model was of the form:

$\beta_{\text {UNEXP }}=\alpha_{0}+\alpha_{1}$ RELSIZE $+\alpha_{2}$ PRIOR $+\alpha_{3}$ RELATION + $\alpha_{4}$ RELVAR $+\alpha_{5}$ BETAB

where: $\beta_{\text {unexp }}$ is the unexplained difference between the calculated and predicted betas of the resultant firm (equity and asset approaches); RELSIZE is the ratio of the pre-merger market capitalizations of the acquiring and target firms, $M C A / M C T$; PRIOR is the proportion of prior holdings of the acquiring firm in the target firm immediately prior to the merger announcement; RELATION is the degree of relatedness of the two participating firms: a value of 1 if they are related, a value of 0 if they are not ${ }^{9}$; RELVAR is the difference in the pre-merger variance of returns of the acquirer and target firms relative to the acquiring firm's variance; BETAB is the absolute value of $\hat{\beta} A_{1}-\hat{\beta} T_{1}$ i.e. the absolute value of the difference in estimated pre-merger betas.

\section{The sample and research methodology}

The study will examine 35 mergers and acquisitions involving publicly listed firms on the Johannesburg Stock Exchange (JSE) between May 1976 and January 1984. The merger sample was identified using the JSE Monthly Bulletin (which lists all mergers) and for inclusion the participating firms had to meet the following criteria:

1. The acquiring firm must not have had two merger announcements less than one year apart. This allows the effects and consequences of a particular merger under study to be isolated. 
2. To minimize estimation problems which thinly traded shares can cause, the annual trading volume of both acquiring and target firms' shares must not have been less than 100000 when averaged over the four years prior to the merger and the year subsequent to the merger in the case of acquiring firms.

3. At least three years of weekly share-price data must have been available prior to the announcement date for both acquiring and target firms, and at least three years of weekly share-price data subsequent to the merger announcement for the acquiring firm.

The merger sample is given in Appendix 1.

For each firm in the sample the dividend-adjusted weekly share-price returns were calculated as the difference in the natural logarithms of the share prices in consecutive weeks after dividends had been taken into consideration. That is

$R_{j t}=\log _{e}\left(\left(P_{j t}+D_{j t}\right) / P_{j t-1}\right)$

where $R_{j t}$ is the return on share $j$ in week $t ; P_{j t}$ and $P_{j t-1}$ are the prices of share $j$ in week $t$ and $t-1$ respectively and $D_{j t}$ is the dividend paid on share $j$ in week $t$. Weekly returns for the JSE Industrial Index (a proxy for the market protfolio) were obtained using the same log return formula, and four weekly returns for the same periods were calculated. Hereafter the four weekly periods will be referred to as months.

For each merger, Sharpe's (1963) market model ${ }^{10}$ was fitted to the data of the acquiring and target firms over the announcement time period $t=-40$ to $t=-6$ months and $t=+1$ to $t=+40$ (where $t=0$ represents the month of merger announcement) for the acquiring firms, and for the period $t=-40$ to $t=-6$ months for the target firms, using the ordinary least squares technique. Time periods $t=-5$ to $t=0$ were deliberately omitted to avoid any abnormal returns just before the merger ${ }^{11}$.

The ordinary least squares fitted betas according to this model for the acquiring and target firms prior to the merger announcement $\left(\hat{\beta} A_{1}\right.$ and $\left.\hat{\beta} T_{1}\right)$ and for the merged firm (the acquirer in its new form) after the announcement $\left(\hat{\beta} A_{2}\right)$ form the basis for this study.

\section{Results}

Table 1 shows summary statistics of the four ordinalvalued independent variables described above.

It can be seen that on average over the sample the target firms had a market capitalization of $39,21 \%$ of that of the acquiring firm before the merger, prior

Table 1 Summary statistics of four ordinal-valued independent variables

\begin{tabular}{lcc}
\hline & Mean & Standard deviation \\
\hline RELSIZE & 0.3921 & 0.3569 \\
PRIOR & 37,22 & 30.53 \\
RELVAR & $-0,7712$ & 2,4759 \\
BETAB & 0,4008 & 0.2978 \\
\hline
\end{tabular}

Table 2 Ordinary least squares estimates of coefficients of equation (3) ( $t$ statistics in parenthesis)

\begin{tabular}{lcc}
\hline Independent variable & \multicolumn{2}{c}{ Dependent variable } \\
\cline { 2 - 3 } & $\begin{array}{c}\text { Unexplained asset } \\
\text { beta shift }\end{array}$ & $\begin{array}{c}\text { Unexplained equity } \\
\text { beta shift }\end{array}$ \\
\hline RELSIZE & 0,3232 & 0,2765 \\
PRIOR & $\left(2,55^{\mathrm{b}}\right)$ & $(1,56)$ \\
& 0,0027 & 0,0006 \\
RELATION & $\left(1,72^{\mathrm{a}}\right)$ & $(0,27)$ \\
& 0,1064 & $-0,0151$ \\
RELVAR & $(1,09)$ & $(-0,11)$ \\
& $-0,0349$ & $-0,0487$ \\
BETAB & $\left(-1,93^{\mathrm{a}}\right)$ & $\left(-1,95^{\mathrm{a}}\right)$ \\
& $-0,2559$ & $-0,3540$ \\
CONSTANT & $(-1,58)$ & $(-1,59)$ \\
$\bar{R}^{2}$ & $-0,1190$ & 0,1156 \\
$F$ & 0,3113 & 0,2127 \\
& $2,62^{\mathrm{b}}$ & 1,57 \\
& $($ significant at & $($ not significant \\
\hline
\end{tabular}

a.b Indicate significance at the $10 \%$ and $5 \%$ levels respectively

holdings of the acquirer in the target were $37,22 \%$, the absolute value of the difference in pre-merger betas between acquiring and target firms was 0,4008 and the relative variance between the two participants was $-0,7712$.

In order to explain the difference between the calculated and predicted betas, regressions were performed of these beta differences on the independent variables mentioned earlier. The regression results are shown in Table 2.

It can be seen that when the difference in estimated and predicted asset betas were used as the dependent variable, three of the five market-related independent variables were significant at least at the $10 \%$ level (PRIOR and RELVAR at the $10 \%$ level, RELSIZE at the $5 \%$ level), while if the difference in estimated and predicted equity beta was used only one of the variables was significant at the $10 \%$ level (RELVAR). This implies that the relative sizes of the participating firms as well as the amount of prior holdings of the acquirer in the target firm impacts relatively more significantly on intrinsic risk than systematic risk. The absolute value of the premerger difference in betas is insignificant in both models, as is the relationship between target and acquiring firms. Note that in the asset beta approach the coefficient of RELATION is positive while in the equity beta case it is negative: all other variables have the same sign in both models. The relative size of the two firms, and the amount of prior holdings of the acquirer in the target firm have a positive effect while the relative premerger variances and the absolute difference in premerger betas both had a negative effect on unexplained beta. For the model which uses differences in equity betas as the dependent variable, the overall fit 
represented by $\bar{R}^{2}$ is weak at 0,2127 (insignificant at the $10 \%$ level) but increases to 0,3113 for the asset betas (significant at the $5 \%$ level), which is reasonable for a model which explains shifts in beta. It is evident therefore that shifts in intrinsic risk are more satisfactorily explained than shifts in systematic risk primarily, it is hypothesized, because the non-linear effect of debt financing has been removed.

The above regression results with unexplained equity beta shifts as the dependent variable are similar to those in in Thompson's (1983) approach which modelled shifts in the acquirer beta. Thompson also found the relative size of the two firms, the relationship between target and acquirer and the absolute differences in pre-merger beta of target and acquiring firm to be insignificant in explaining beta changes, while the difference in the premerger variance of returns of the two firms relative to the acquiring firm's variance was significant at the $10 \%$ level. These variables in Thompson's paper all had the same signs as in the current study except for the variable RELATION. However, this may well be due to the different definitions of the degree of relatedness of two firms used in the two studies. Both the $\bar{R}^{2}$ value and the $F$ statistic were similar in magnitude to those calculated by Thompson in the equity beta case.

Table 3 contains univariate statistics on the calculated and predicted betas, and their difference for both the asset beta and equity beta approaches.

It will be seen that both approaches show the calculated betas to be somewhat larger than that predicted by capital market theory. This difference amounts to 0,1058 for the asset beta case (not significant at the $10 \%$ level) and a, 1422 for the equity beta case (significant at the $5 \%$ level). Thus the equity beta approach shows that there has been some significant shift in systematic risk which is less pronounced under the asset beta approach. In 22 cases the calculated beta was larger than the predicted beta and in 13 cases it was smaller for both asset and equity beta approaches supporting the thesis that merger produces some upward shift in both equity and asset beta over and above that indicated by capital market theory.

In order to gain some insight into these results and

Table 3 Average values of $\beta A_{2}, E\left(\beta A_{2}\right)$ and their difference (standard deviation in parenthesis)

\begin{tabular}{lccc}
\hline & Asset & Equity & Difference \\
\hline$\beta A_{2}$ & 0,8362 & 1,0959 & \\
$E\left(\beta A_{2}\right)$ & $(0,3293)$ & $(0,3361)$ & \\
& 0,7304 & 0,9537 & \\
$\beta A_{2}-E\left(\beta A_{2}\right)$ & $(0,2498)$ & $(0,2254)$ & \\
& 0,1058 & 0,1422 & $-0,0364$ \\
$t$ statistic & $(0,2922)$ & $(0,2861)$ & $(0.2892)$ \\
& $1,5158^{\mathrm{a}}$ & $2,0789^{\mathrm{b}}$ & 0,5268 \\
\hline
\end{tabular}

a Not significant at the $10 \%$ level

bignificant at the $5 \%$ level
Table 4a Unexplained beta shifts and relationship of merging firms (standard deviation in parenthesis)

\begin{tabular}{lcccc}
\hline & $\begin{array}{c}\text { Asset } \beta \\
\text { case }\end{array}$ & $\begin{array}{c}\text { Equity } \beta \\
\text { case }\end{array}$ & Difference & $t$ statistic \\
\hline Related & 0,1007 & 0.1159 & $-0,0152$ & $-0,162$ \\
acquirer & $(0,2354)$ & $(0.2420)$ & $(0,2392)$ & \\
Unrelated & $\mathbf{0 , 0 6 1 1}$ & 0,1579 & $-0,0968$ & $-0,920$ \\
acquirer & $(0,2897)$ & $(0.3992)$ & $(0,3490)$ & \\
Difference & $\mathbf{0 , 0 3 9 6}$ & $-0,0420$ & & \\
& $(0,2715)$ & $(0,3501)$ & & \\
t statistic & 0,417 & $-0,343$ & & \\
\hline
\end{tabular}

Table 4b Signs of unexplained beta shifts

\begin{tabular}{lccr}
\hline & Positive & Negative & \\
$\begin{array}{l}\text { Asset beta } \\
\text { Related }\end{array}$ & 9 & 4 & $\chi^{2}=1.742$ \\
$\begin{array}{l}\text { acquirer } \\
\text { Unrelated } \\
\text { acquirer } \\
\text { Total }\end{array}$ & 13 & 9 & $\begin{array}{r}\text { not significant at } \\
\text { the } 10 \% \text { level }\end{array}$ \\
$\begin{array}{l}\text { Equity beta } \\
\text { Related } \\
\text { acquirer } \\
\begin{array}{l}\text { Unrelated } \\
\text { acquirer }\end{array}\end{array}$ & 22 & 13 & \\
$\begin{array}{l}\text { Total } \\
\text { Tot }\end{array}$ & 9 & 4 & $\chi^{2}=1.742$ \\
& 22 & 13 & not significant at \\
the $10 \%$ level
\end{tabular}

compare them to those of Thompson (1983), the sample was partitioned into related and unrelated mergers (see Table 4a).

It was found that the equity beta approach indicated a tendency for the related acquirers to show a smaller unexplained systematic risk than the unrelated acquirers, and the asset beta approach indicated that the related acquirers had larger unexplained shifts in risk. These figures are not significant, however, showing that diversification in itself does not affect the unexplained risk of the resulting acquiring firm under either the equity or asset beta approaches. It is interesting to note that the variability of the unexplained beta shifts between the two approaches is much larger for the unrelated (conglomerate) acquirers. Thompson's model showed similar, although more marked, differences in equity beta when related and unrelated mergers were considered. In fact related mergers actually decreased the difference in equity beta.

Table $4 \mathrm{~b}$ shows the signs of the excess risk terms after partitioning by relationship.

A $x^{2}$ test for dependence between the two variables' relationship and sign of unexplained beta shifts showed no significant dependence between them, supporting the evidence of Table $4 a$. 


\section{Conclusions}

The univariate tests showed there are unexplained (according to capital market theory) shifts in beta due to merger. The shift in equity betas was greater than asset betas, leading to the conclusion that the financial leverage in the acquiring and target firms was a cause of this shift. Furthermore, it was shown that the degree of diversification in the merger was not a factor in the determination of unexplained systematic risk changes of the acquiring firm above what might have been expected.

It is seen that computing unexplained shifts in equity beta rather than the equity beta difference of the acquirer, yielded similar conclusions in this study to that of Thompson, implying that target and acquirer equity beta are similar in the sample considered.

The multivariate regression model presented in this paper clearly demonstrated that shifts in asset betas (intrinsic operating risk) are more satisfactorily explained in the regression model than shifts in equity betas and that the prior holding position, relative size and total risk are significant in explaining beta shifts using this approach. It is suggested that the removal of the debt effect removes a confounding non-linear effect and allows the explanatory variables to present more clearly.

\section{Acknowledgement}

Financial assistance rendered by the Human Sciences Research Council towards the cost of this research is hereby acknowledged. Opinions expressed or conclusions arrived at are those of the authors and not necessarily those of the HSRC.

\section{Notes}

1. See, for example, Halpern (1973), Mandelker (1974), Langetieg (1978), Dodd (1980), Bhana (1987) and van den Honert et al. (1988).

2. Thompson (1983) used three different measures of conglomerateness:

$$
\begin{aligned}
& \text { cong } 1=\frac{\text { the number of industries new to the acquirer }}{\text { number of acquirer's pre-merger industries }} \\
& \operatorname{cong} 2=\frac{\text { the number of industries new to the acquirer }}{\text { number of acquired firm's industries (post-merger) }}
\end{aligned}
$$

cong $3=$ a dummy variable equal to 1 if at least $50 \%$ of the acquired firm's industries are new to the acquirer and not more than two are not, and 0 otherwise.

3. This point was noted by Thompson (1983), who used the change in the ratio of long-term debt to total assets after the merger as an independent variable. As will be seen later, in his study the debt position of the resultant acquiring firm is modelled in as part of the dependent variable.

4. See, for example, Ilill \& Stone (1980).

5. Assume $a \%$ of available wealth is put into asset $X$ with systematic risk $\beta_{x}$ and $(1-a) \%$ of available wealth is put into asset $Y$ with systematic risk $\beta_{y}$, then the portfolio systematic risk, $\beta_{p}$, is

$$
\begin{aligned}
& \beta_{p}=\frac{\operatorname{Cov}\left(R_{p}, R_{m}\right)}{\operatorname{Var}\left(R_{m}\right)} \text { where } R_{p}=\text { return on the portfolio and } \\
& R_{m}=\text { return on the market } \\
& =\frac{E\left[\left(R_{p}-E\left(R_{p}\right)\right)\left(R_{m}-E\left(R_{m}\right)\right)\right]}{\operatorname{Var}\left(R_{m}\right)} \begin{array}{l}
\text { by definition of the co- } \\
\text { variance }
\end{array}
\end{aligned}
$$

But since returns are additive, i.e. $R_{p}=a R_{x}+(1-a) R_{y}$, where $R_{x}=$ return on asset $X$, and $R_{y}=$ return on asset $Y$,

$$
\beta_{p}=\frac{E\left[\left(a R_{x}+(1-a) R_{y}-E\left(a R_{x}+(1-a) R_{y}\right)\left(R_{m}-E\left(R_{m}\right)\right)\right]\right.}{\operatorname{Var}\left(R_{m}\right)}
$$$$
=\frac{E\left[\left(a R_{x}+(1-a) R_{y}-a E\left(R_{x}\right)-(1-a) E\left(\mathrm{R}_{y}\right)\right)\left(R_{m}-E\left(R_{m}\right)\right)\right]}{\operatorname{Var}\left(R_{m}\right)}
$$$$
=\frac{E\left[\left(a\left(R_{x}-E\left(R_{x}\right)\right)+(1-a)\left(R_{y}-E\left(R_{y}\right)\right)\right)\left(R_{m}-E\left(R_{m}\right)\right)\right]}{\operatorname{Var}\left(R_{m}\right)}
$$$$
=a \frac{E\left(R_{x}-E\left(R_{x}\right)\right)\left(R_{m}-E\left(R_{m}\right)\right)}{\operatorname{Var}\left(R_{m}\right)}+(1-a) \frac{E\left(R_{y}-E\left(R_{y}\right)\right)\left(R_{m}-E\left(R_{m}\right)\right)}{\operatorname{Var}\left(R_{m}\right)}
$$

$$
=a \frac{\operatorname{cov}\left(R_{x}, R_{m}\right)}{\operatorname{Var}\left(R_{m}\right)}+(1-a) \frac{\operatorname{cov}\left(R_{y}, R_{m}\right)}{\operatorname{Var}\left(R_{m}\right)}
$$

$=a \beta_{r}+(1-a) \beta_{y}$

6. This implies that beta is stationary over the short term. Although controversial,this has been demonstrated by Jensen (1969). Fabozzi \& Francis (1977) and on the JSE by Bradfield, Affleck-Graves \& Barr (1982).

7. The market value of a firm's debt can be measured as the market value of the bonds issued by the firm. Most South African firms do not have publicly issued debt and their debt is thus variable interest debt in a bank. In this case the market value of the firm's debt is merely the book value of the debt.

8. See, for example. Thompson (1983), Fabozzi \& Francis (1979) and Dhingra (1982)

9. A merger was classified as 'related' if the target firm was in a related industry to the acquiring firm and the acquiring firm was operating in a specific industry, i.e. was not of a conglomerate nature. All other mergers were classified as 'unrelated'.

10. Sharpe's market model can be stated as

$R_{j t}=\alpha_{j}+\beta_{i} R_{m t}+\epsilon_{j t}$

where $R_{\mu \prime}$ is the reurn on share $j$ in period $t: R_{m t}$ is the return on the market portfolio in the same period $t: \beta$, is a relative measure of the systematic risk of security $j$; $\alpha$, is a constant; $\epsilon_{j t}$ is a stochastic error term associated with $R_{j p} ; \epsilon_{j t}$ is assumed to have expectation of 0 . to have fixed variance over time and to be independent over time. 
11. As far as the target firms are concemed there is a wealth of evidence that large abnormal retums are achieved in the months prior to the merger announcement. See Mandelker (1974). Dodd (1980). Bhana (1987) and Keown \& Pinkerton (1981)

\section{References}

Bhana. N. 1987. Take-over announcement and insider trading activity on the Johannesburg Stock Exchange. S. Afr. J. Bus. Mgmi. . vol. 18, 196-208.

Bradfield. D.J.. Affleck-Graves. J.F. \& Barr. G.D.I. 1982. Stability test for alphas and betas over bull and bear market conditions on the Johannexburg Stock Exchange. Unpublished Report. Department of Mathematical Statistics. Liniversity of Cape Town. $17 \mathrm{p}$.

Brealey. R. \& Myers. S. 1981 . Principles of Corporate Finance. New York.

Copeland. T.E. \& Weston. J.F. 1983 Financial Theory and Corporate Policy: New York.

Dhingra. H.L. 1982. The impact of accounting variables on stock market measures of risk. Account. Bus. Res. 193-205.

Dodd. P. 1980. Merger proposals. management discretion and stockholder wealth. J. Finan. Econ.. vol. 8. 105-138.

Fabozzi. F.J. \& Francis. J.C. 1977. Stability tests for alphas and betas over bull and bear market conditions. J. Fin. . vol. 32. 1093-1099.

Fabozzi. F.J. \& Francis. J.C. 1979. Industry effects and the determinants of beta. Quart. Rev. Econ. Bus.. vol. 19. 61-74.

Halpern. P.J. 1973. Empirical estimates of the amount and distribution of gains to companies in mergers. J. Bus. . vol. 1. 554-575.

Hamada. R.S. 1972. The effect of the firm's capital structure on the systematic risk of common stocks. J. Fin.. vol.27. 435-452.

Hill. N.C. \& Stone. B.K. 1980 . Accounting betas. systematic operating risk and financial leverage: $A$ risk-composition approach to the determinants of systematic risk. J. Fin. Quant. Anal. vol. 15. 595-637.

Jensen. M.C. 1969. Risk, the pricing of capital assets. and the evaluation of investment portfolios. J. Bus. . vol. 42. 167-247.

Joehnk. M.D. \& Nielsen, J.F. 1974. The effects of conglomerate merger on systematic risk. J. Fin. Quant. Anal. , vol.9. 215-225.

Keown. A.J. \& Pinkerton, J.M. 1981. Merger announcements and insider trading activity: An empirical investigation. $J$. Fin.. vol. 36. 855-869.

Langetieg. T. 1978. An application of a three factor performance index to measure stockholder gains from merger. J. Finan. Econ. vol. 6, 365-384.

Levy, H. \& Sarnat, M. 1970. Diversification portfolio analysis and the uneasy case for corporate mergers. J. Fin., vol. 25 , 795-802.

Mandelker, G. 1974. Risk and return: The case of merging firms. J. Finan. Econ., vol. 1, 303-335.
Mueller. D.C. 1977. The effects of conglomerate mergers. J. Banking Fin. vol. 1. 315-347.

Rubenstein. M.E. 1973. A mean-variance synthesis of corporate financial theiry. J. Fin. . vol.28. 167-182.

Sharpe. W.F. 1963. A simplified model for portfolio analysis. Manage. Sci. vol.9. 277-293.

Thompson. R.S. 1983. Diversifying mergers and risk: Some empirical tests. J. Econ. Studies. vol. 10. 12-21.

Van den Honert. R.C.. Barr. G.D.I.. Affleck-Graves. J.F. \& Smale. G. 1988. Merger announcements and share price return - the role of the relationship between acquiring and target firms. S. Afr. J. Bus. Mgmt vol. 19. 1-10.

Wagner. W.h. \& Lau. S.C. 1971. The effect of diversification on risk. Finan. Anal. J.. vol. 26. 7-13.

\section{Appendix 1 The merger sample}

\begin{tabular}{|c|c|c|}
\hline Acquining firm & Target firm & $\begin{array}{c}\text { Announcement } \\
\text { date }\end{array}$ \\
\hline Anglo American Corp & Rand Selections & $19 / 01 / 77$ \\
\hline Anglo American Ind Corp & Brinnzeel Plywood & $1808 / 76$ \\
\hline Barlow Rand & CJ Fuchs & $26 / 11 / 80$ \\
\hline Blue Circle & Hubert Davies & $23.03 / 7$ \\
\hline CG Smith Sugar & Illovo Sugar & $09109 m$ \\
\hline Amaleamated Retail & ABC Shoe Company & $20 \cdot 0 / 83$ \\
\hline Anglo Alpha Cement & Hippo Holdings & 160377 \\
\hline Dorman Long & Bus Industries SA & $19: 1078$ \\
\hline Federale Volksbeleggings & SA Druggists & $09 / 08 / 83$ \\
\hline General Mining & Lnion Copporation & $19 / 1279$ \\
\hline General Mining & Xactics & $1407 / 83$ \\
\hline Hunt Leuchars and Hepburn & WF Johnstone & 101381 \\
\hline Johannesburg Cons Inv & Tavistock Collieries & $24 / 03 / 81$ \\
\hline Johannesburg Cons Inv & Steelbright & 141278 \\
\hline Kohler & DRG (SA) & $03 / 02 / 83$ \\
\hline Metal Box & Metal Rolling \& Tube Hold & $29 / 0877$ \\
\hline Nampak & Premier Paper & $2004 / 83$ \\
\hline Rembrandi Group & Oude Meester & 1118878 \\
\hline Sage Holdings & Schachat Holdings & $30 \times 1178$ \\
\hline Sam Steele & Steel and Barnet & $31 / 07 / 78$ \\
\hline Union Platinum & Potgietersrys Platinum & $17 \pi 05 / 76$ \\
\hline Union Platinum & Waterval Platinum & $17 / 05 / 76$ \\
\hline Seardel & Dubin Investments & $06 / 03 / 81$ \\
\hline Sentrachem & Federale Kunsmis & $29 / 1179$ \\
\hline UDC Holdings & Ryan Nigel Holdings & $04 / 0+77$ \\
\hline Metkor Investments & Fouler Holdings & $05 / 0478$ \\
\hline Tongaat-Huletı & Tongaat Corogroup & $0209 / 83$ \\
\hline Union Corporation & Geduld Investments & $26007 / 76$ \\
\hline Volkskas Group & Bank OFS & $25 / 09 / 81$ \\
\hline W \& A Investments & Burlington Hosiery & $11 \times 0577$ \\
\hline Woolworths & Truworths & $1603 / 81$ \\
\hline Metkor Investments & Wispeco & $27 / 11 / 79$ \\
\hline Metkor Investments & Hant Ltd & $27 / 11 / 79$ \\
\hline Lucem Holdings & Brick \& Clay Holdings & $2202 / 80$ \\
\hline CNA Investments & Gallo Africa & $31 / 03 / 83$ \\
\hline
\end{tabular}

